\title{
Virpi Timonen (2016). Beyond Successful and Active Ageing: A Theory of Model Ageing. Bristol, UK: Policy Press, 119 pp. ISBN 978144733017 2 (hardback)
}

\author{
REVIEWED by DoRa TADIC*
}

The book Beyond Successful and Active Ageing: A Theory of Model Ageing by Virpi Timonen provides a new approach to successful and active ageing. In it, the author offers both a critique and constructive advice on these concepts, aiming to set grounds for a new theory of model ageing. This review will summarise the main points Timonen makes in the five chapters of the book, and will also situate the book around existing research on successful and active ageing, showing the main strengths of the book and offering some critique.

The first chapter offers a motive behind developing a new theory. Timonen's main argument is based on the paradoxes that exist in ageing societies and that construct older people in ambivalent terms. Older people are expected to be active and in control of their lives, but are at the same time perceived as individuals who lack agency (Timonen 2016). Furthermore, researchers, policy makers and marketing experts often treat them as a homogenous group, while the differences based on their gender, sexual orientation, social class and ethnicity are mostly overlooked. This creates a homogenous image of the older population and the belief that there is a single ageing model that can and should be applied to everyone.

* Dora Tadic, School of Social and Political Science, The University of Edinburgh, Edinburgh, Scotland 
International Journal of Ageing and Later Life

These and other paradoxes, "the puzzle of gender and social class blindness," "the puzzle of assuming strong agency in welfare production" and "the paradox of turning the problem into the solution" (Timonen 2016: 2-3), lead Timonen to offer a new theory of model ageing.

The second chapter explores the concept of successful ageing. In it, Timonen argues that one of the main critiques of successful ageing is the lack of an agreed definition of the concept. Even though a number of researchers tried to define successful ageing (e.g. Havighurst 1961; Peterson \& Martin 2015; Rowe \& Kahn 1997), it is difficult to agree on a single definition because of the different perception of the concept of successful ageing between the researchers and their participants. Timonen further argues that successful ageing has become "a commodity for sale" (Timonen 2016: 23). This is concurrent with Katz and Marshall (2003), who argue that products aimed at the older population, such as Viagra, and various medical and rejuvenating treatments are often tailored to suit business and medical entrepreneurs who are not only accommodating but also actively creating a new, and very large, consumer group (Loe 2004).

In the third chapter, Timonen argues that active ageing is a policy term, used mainly as a response to population ageing in Europe. Even though active ageing takes a more life-course oriented approach than successful ageing, it is still defined in a framework of economic and productivist perspective, making it a base for global and European policy developments. One of the examples is policies on independent living, which imply all older people are capable of living on their own without any major problems. The other is aimed towards policies on economic contributions, such as prolonged working life and prevention of age discrimination. Both examples show a lack of a person-centred approach, an issue often seen in geriatric medicine as well (e.g. in the work by Bentrott \& Margrett 2011). The individual needs of older people, therefore, lack recognition at policy level, resulting in active ageing policies that cover only a number of "model" citizens who fit the model of successful ageing.

Timonen's division of older people into "model" and "anti-model" citizens serves to show how difficult it is to model ageing. A "model" citizen is a person who lives by the successful and active ageing concepts, and the "anti-model" citizen is a person who deviates from those concepts for whatever reason. As the context in which people live is relevant for 
Beyond successful and active ageing. Book review

their behaviour as "model" or "anti-model" citizens, Timonen wonders why some people behave as "model" citizens in an environment that does not encourage successful and active ageing, and why there are "anti-model" citizens in countries that reward it. Understanding this behaviour is the key to developing a new theory of model ageing, because it can guide new research to focus on various social determinants of successful and active ageing, such as the life course, which Hendricks (2012) proposes is one of the key aspects in studying ageing, and the agency older people actually have over their own ageing process (Timonen 2016).

Timonen's model ageing theory is of course not the first one to explore the downsides of the successful and active ageing models, and to propose a different approach to ageing. For example, the model of optimal ageing discussed by Aldwin and Gilmer (2004) allows for different ways of ageing well, depending on the person's resources, health status and the choices they make. Similarly, the model of harmonious ageing, by Liang and Luo (2012), is based on the Yin-Yang philosophy and understands ageing as a balance based on differences rather than on uniformity, which links to Timonen's critique of the homogeneity of the successful ageing model. Both of these theories are based on the downsides of successful ageing, trying to include the aspects of ageing that the successful ageing model has neglected. However, while successful and active ageing are models which have policy and research implications, optimal and harmonious ageing are still only talked about on a theoretical level, perhaps lacking institutionalised support that would help transform them into new model ageing policies.

As difficult it might be to propose a new theory of ageing, Timonen argues that it is necessary to at least try to do it. In an attempt to move towards a new model, she proposes 10 postulates that combine "policy ideals, commercial depiction and academic conceptualisations" (Timonen 2016: 89; emphasis in original) of model ageing. The ones most relevant for the discussion argue that there are actors who have an interest in controlling and classifying population ageing for capitalist gains, that model ageing expects that people with least resources adapt and change the most and that, in the future, there will be "increasing exhortations on older adults to adapt and change their behaviours" (Timonen 2016: 94), creating more negative consequences for the disadvantaged. 
International Journal of Ageing and Later Life

In conclusion, Timonen does not solely argue for an immediate development of a new theory of model ageing. She proposes looking beyond the concepts of successful and active ageing, and focusing on "what really matters: how to help those who struggle most to reach good outcomes in old age" (Timonen 2016: 99). Timonen's arguments make this book an excellent addition to the field of ageing studies, especially to the area exploring successful and active ageing, and their alternatives. It is also a good starting point for developing a new way of thinking about the older population, approaching them as individuals rather than as a new target group for a plethora of anti-ageing products.

\section{References}

Aldwin, C. M. \& Gilmer, D. F. (2004). What is optimal aging? In C. M. Aldwin \& D. F. Gilmer (eds.), Health, Illness, and Optimal Aging: Biological and Psychosocial Perspectives (pp. 303-322). Thousand Oaks, CA: Sage.

Bentrott, M. \& Margrett, J. (2011). Taking a person-centered approach to understanding sexual expression among long-term care residents. Ageing International 36(3): 401-417.

Havighurst, R. J. (1961). Successful aging. The Gerontologist 1(1): 8-13.

Hendricks, J. (2012). Considering life course concepts. Journals of Gerontology - Series B Psychological Sciences and Social Sciences 67(2): 226-231.

Katz, S. \& Marshall, B. (2003). New sex for old: Lifestyle, consumerism, and the ethics of aging well. Journal of Aging Studies 17(1): 3-16.

Liang, J. \& Luo, B. (2012). Toward a discourse shift in social gerontology: From successful aging to harmonious aging. Journal of Aging Studies 26: $327-334$.

Loe, M. (2004). Sex and the senior woman: Pleasure and danger in the Viagra era. Sexualities 7(3): 303-326.

Peterson, N. M. \& Martin, P. (2015). Tracing the origins of success: Implications for successful aging. The Gerontologist 55(1): 5-13.

Rowe, J. \& Kahn, R. (1997). Successful Aging. New York: Random House.

Timonen, V. (2016). Beyond Successful and Active Ageing: A Theory of Model Ageing. Bristol: Policy Press. 